\title{
Preface to special edition on learner discipline problems in schools
}

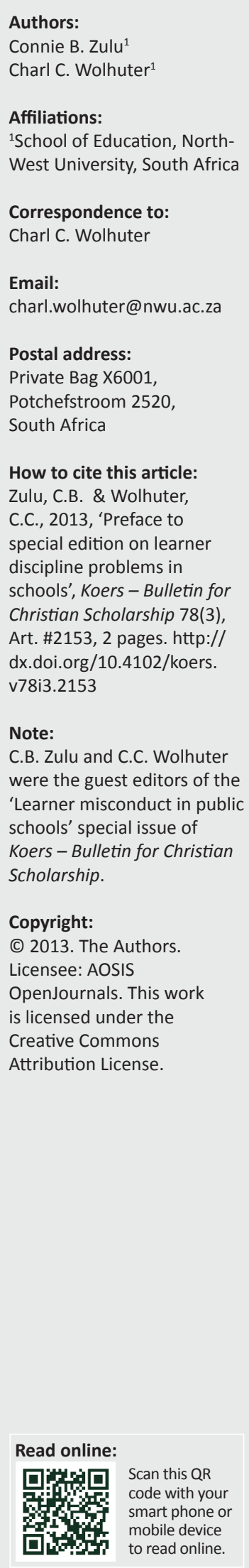

Learner misconduct in public schools continues to be a source of problems for teachers, principals and parents. It is of grave concern to educationalists nationally and internationally. Its persistence, despite all efforts to curb it, presents a serious challenge to the existence of a future society built upon sound moral, cultural and Christian values. This special edition of Koers Bulletin for Christian Scholarship on learner misconduct in public schools centres on current local and international debates on learner misconduct. It provides a forum for educationalists, locally and internationally, to engage with this issue from a multidisciplinary perspective, not just in a general way but in a deeper and more profound manner. In essence, the articles in this issue concern themselves not only with the state of learner discipline in public schools but also with the Christian perspective as a lens through which to view this problem. Whilst the articles aim to provide readers with a broad array of perspectives on learner misconduct, the principle of positive discipline is foregrounded in the arguments.

De Wet uses a four-level, social-ecological model to underpin her study on individual, family, institutional and societal risk factors for bullying. Her article 'Educators' perspectives on risk factors for learner-on-learner bullying' makes an important suggestion, arguing that although risk-focused prevention strategies may lead to a reduction in bullying, prevention strategies should not only target these (negative) factors but try to promote protective factors on all four social-ecological levels.

In their article 'Ouerskap en die dissiplinering van vyf- tot sesjariges', Rossouw and Oosthuizen recognise the role of parents in disciplining children during their formative years. The article reports on the opinions of South African parents regarding the behaviour of their five- to sixyear olds from a bio-ecological perspective as postulated by Bronfenbrenner and supported by a critical Christian worldview. Parents report on their children's behaviour which they perceive as problematic and explain the strategies they apply and the nature of the interventions they choose to deal with their children's misbehaviour.

Oosthuizen's article 'Die positivering van geborgenheid met die oog op ' $n$ meer gedissiplineerde onderringleeromgewing' argues for a deconstruction of constructs such as geborgenheid and its actualisation in the teaching and learning environment to enhance teaching and learning.

Serame, Oosthuizen, Wolhuter and Zulu, in their article entitled 'An investigation into disciplinary methods used by teachers in secondary township schools in South Africa', probe the incidence of discipline problems amongst learners and their effect on teachers. They also probe teachers' methods of maintaining discipline and the effectiveness of those methods. The experiences of both teachers and learners in the surveyed schools revealed that discipline is not at all sound and that discipline problems in these schools are more serious than the international norm.

'Addressing learner behaviour in a classroom: Action towards hope' offers a fresh approach to the problem of learner discipline. The authors, LeeFon, Jacobs, Le Roux and De Wet argue for a non-punitive form of discipline which involves collaboration rather than confrontation with learners. They argue for the acknowledgement, respect and appreciation of learners and for teachers to 'empower themselves with knowledge and a better understanding of the concept of discipline and not see the classroom as a battlefield'.

In the article 'Bydraende faktore tot leerderdissiplineprobleme: ' $n$ Multiveranderlike analise', Wolhuter, Eloff, Oosthuizen and Van der Walt make a ground-breaking contribution to the scholarly literature on discipline problems amongst learners in South African schools. For the first time, discipline problems are studied as the outcome of a confluence of a multitude of factors, extending the literature corpus which had up to now focused on one set of causal factors underlying discipline problems in schools. 
In their article 'Disciplining aggressive learners in rural South African secondary schools', Steyn and Singh offer insights into the causes, the forms, the consequences and the psychological effects of aggression and strategies to manage aggression in learners.

Wolhuter, Van der Walt and Potgieter's article 'The image of the teacher held by learners from 10 different countries: A new perspective on the causes of learner discipline problems' reports on research that investigated the image of teachers held by school learners and how that image can contribute towards disrespect for teachers and thus be one of the factors behind the incidence of learners' disciplinary problems.

In contrast, the influence of learners and their disciplinary problems on teachers and the role of other stakeholders in this regard is the topic of De Witt and Lessing's article 'Teachers' perception of the influence of learners' undisciplined behaviour on their working life and of the support of role-players'. From their empirical research, it appears that undisciplined behaviour is the source of irritation, makes demands on teachers' tempers and causes aggression. The majority of teachers reported that they enjoy sufficient support from the school's governing body, but they are not satisfied with the support from parents and the department of education.
Wolhuter and Russo's article 'Dealing with incidences of serious learner discipline problems in South African schools: Guidelines from international-comparative perspectives' highlights the practices and experiences of eight diverse countries regarding legally sound methods of dealing with incidences of serious disciplinary problems. These eight countries are: Brazil, England, Turkey, Singapore, Malaysia, China, Australia and New Zealand. From their experience, guidelines for South Africa are extracted.

Finally, in their article 'Addressing learner discipline problems: An integrated holistic approach', Kourkoutas and Wolhuter point out the fallacy of the reductionist behaviouristic conceptualisation of problems concerning learner discipline and the handling thereof, which has hitherto characterised education practice and scholarly literature alike. Instead, the authors propose a more holistic, integrated conceptualisation and develop a model to that effect.

In total, this set of articles offer a Christian scholarly look at the problem of learner discipline in South African schools from a variety of points of view, including that of teachers and learners, a conceptual educational-philosophical angle, a legal angle and a comparative-international angle, all in the hope that this collection will make a contribution towards addressing the problem of learner misconduct in a Christian way. 